\title{
Erratum to: Long-acting methylphenidate formulations in the treatment of attention- deficit/hyperactivity disorder: a systematic review of head-to-head studies
}

David Coghill ${ }^{*}$, Tobias Banaschewski², Alessandro Zuddas ${ }^{3}$ Antonio Pelaz ${ }^{4}$, Antonella Gagliano ${ }^{5}$ and Manfred Doepfner ${ }^{6}$

\section{Correction}

After publication of this work [1], we noted that a figure reproduced from Lopez et al. [2], was revised in an erratum.

In Figure three (Fig. 1 here), the uppermost solid line represents placebo and the lower solid line (at $0.5 \mathrm{~h}$ ), represents Ritalin $\mathrm{LA}^{\circ} 20 \mathrm{mg}$ capsule. In addition, labelling of the $\mathrm{x}$-axis should read " $0.5,1,2,3,4,6,8$ " hours.

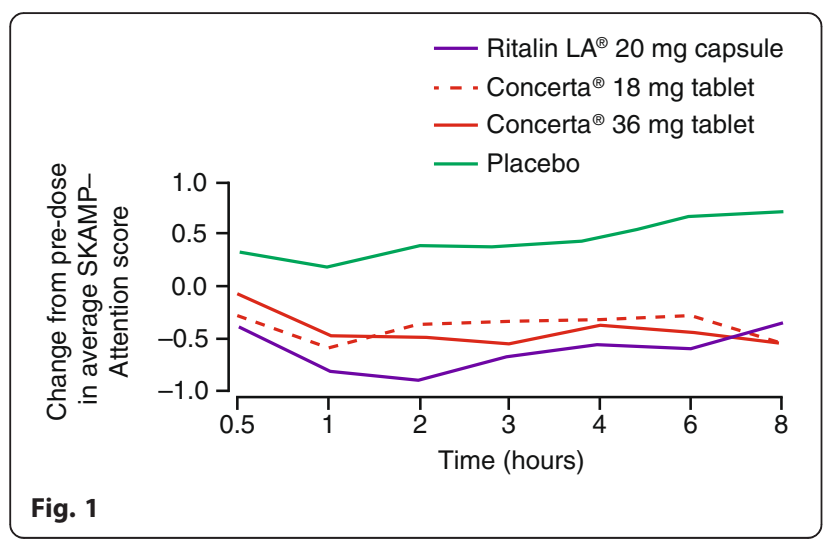

\footnotetext{
* Correspondence: d.r.coghill@dundee.ac.uk

David Coghill and Tobias Banaschewski are joint first authors.

Antonella Gagliano and Manfred Doepfner are joint last authors.

'Division of Neuroscience, Medical Research Institute, Ninewells Hospital and Medical School, Dundee, UK
}

\section{() Biomed Central}

(c) 2015 Coghill et al. Open Access This article is distributed under the terms of the Creative Commons Attribution 4.0 International License (http://creativecommons.org/licenses/by/4.0/), which permits unrestricted use, distribution, and reproduction in any medium, provided you give appropriate credit to the original author(s) and the source, provide a link to the Creative Commons license, and indicate if changes were made. The Creative Commons Public Domain Dedication waiver (http://creativecommons.org/publicdomain/zero/1.0/) applies to the data made available in this article, unless otherwise stated.

\begin{abstract}
Author details
'Division of Neuroscience, Medical Research Institute, Ninewells Hospital and Medical School, Dundee, UK. ${ }^{2}$ Department of Child and Adolescent

Psychiatry, Central Institute of Mental Health, Medical Faculty of Mannheim, University of Heidelberg, Mannheim, Germany. ${ }^{3}$ Department of Biomedical Sciences, University of Cagliari, Cagliari, Sardinia, Italy. ${ }^{4}$ Department of Child and Adolescent Psychiatry, Hospital Clinico Universitario San Carlos, Madrid, Spain. ${ }^{5}$ Department of Pediatric Science, University of Messina, Policlinico Universitario G. Martino, Messina, Italy. ${ }^{6}$ Department of Child and Adolescent Psychiatry, University of Cologne, Cologne, Germany.
\end{abstract}

Received: 5 August 2015 Accepted: 5 August 2015

Published online: 25 August 2015

\section{References}

1. Coghill D, Banaschewski T, Zuddas A, Pelaz A, Gagliano A, Doepfner M. Long-acting methylphenidate formulations in the treatment of attentiondeficit/hyperactivity disorder: a systematic review of head-to-head studies. BMC Psychiatry. 2013;13:237.

2. Lopez F, Silva R, Pestreich L, Muniz R. Comparative efficacy of two once daily methylphenidate formulations (Ritalin LA and Concerta) and placebo in children with attention deficit hyperactivity disorder across the school day. Paediatr Drugs. 2003;5:545-55.

\section{Submit your next manuscript to BioMed Central and take full advantage of:}

- Convenient online submission

- Thorough peer review

- No space constraints or color figure charges

- Immediate publication on acceptance

- Inclusion in PubMed, CAS, Scopus and Google Scholar

- Research which is freely available for redistribution 